\title{
COMMENT
}

DOI: $10.1057 / s 41599-018-0102-z$

\section{Geographies of emotional and care labour}

\author{
Jessica Parish (i) ${ }^{1} \&$ Jean Michel Montsion ${ }^{2}$
}

\begin{abstract}
Recent years have witnessed shifts in the social organisation of emotional and care labour, especially as they intersect with new global trends in migratory patterns and international mobility, the restructuring of social reproduction and public-private divides, as well as the flexibilization of labour markets and a resurgence of unpaid labour such as volunteer work. With a focus on emotions and affect as a central epistemological and methodological orientation, this essay aims to draw connections between three distinct but related bodies of feminist scholarship: social reproduction theory, studies of emotional labour, and emotional geographies. The paper frames these approaches relative to the project of understanding the spatial dimensions of forms of emotional and care labour in neoliberal times.
\end{abstract}

\footnotetext{
${ }^{1}$ City Institute, York University, 4700 Keele Street, Toronto, ON M3J 1P3, Canada. ${ }^{2}$ Department of Multidisciplinary Studies, Glendon College, York University, 2275 Bayview Ave., Toronto, ON M4N 3M6, Canada. Correspondence and requests for materials should be addressed to J.P. (email: jparish2009@gmail.com)
} 


\section{Introduction}

his essay introduces an article collection on the geographies of emotional and care labour, ${ }^{1}$ and builds on various calls to consider how emotions are significant sites of enquiry to better understand the social world (i.e., Ahmed, 2004; Anderson and Smith, 2001; Hochschild, 2012). In framing this collection we have chosen to highlight connections between three distinct but related bodies of feminist scholarship: social reproduction theory, studies of emotional labour, and emotional geographies. Writing over half a century ago, Jean-Paul Sartre (1960 pp 33-38) argued that focusing on emotions brings attention to the unpredictable, disorganised and symbolic aspects of human lives that are often marginalised by traditional methods of enquiry. Taking emotions seriously in the study of social, political, and economic life can therefore be used as a theoretical and methodological tool for destabilising the binaries inherited from the Enlightenment.

Nonetheless, much contemporary social sciences and humanities scholarship ignores or downplays the importance of emotions to the benefit of an epistemological and methodological preference for rationality. This commitment goes hand in hand with a modernist, capitalist, and colonial enterprise that separates and prioritises inquiries into the public over the private, emphasises the agency of some bodies over others, and privileges sight and the visual over the senses of touch, olfaction, and taste (Irigaray, 1985; Laporte, 2002). The essays in the collection associated with this paper highlight that emotions are an active part of social worlds, especially when these worlds are understood as fundamentally produced and reproduced through forms of emotional and care labour. Accordingly, the collection places these forms of world-making activity front-and-centre as crucial sites of enquiry into the workings of local and global political economies.

\section{Theorising social reproduction}

Initially developed by Marxist Feminists in the 1970s and 1980s to respond to the marginalisation of women and domestic labour in studies of political economy, the theory of social reproduction is undergoing a renaissance today (Andrucki et al., 2017; Bhattacharya 2017; Furgeson et al., 2016; Katz, 2017). To paraphrase Tithi Bhattacharya (2017), the theory of social reproduction asks: what labour produces the commodity of labour power? (p 1). Emerging from a critique of gender blind Marxist theory, social reproduction challenges the narrowness of an exclusive focus on production and highlights "naturalised" forms of unwaged and/or under-valued feminised labour that performs the essential task of reproducing, on a daily and generational basis, the labour force upon which capital depends (Furgeson et al. 2016). As geographer Cindy Katz points out, under capitalism, this is necessarily a differentiated labour force, and, therefore, social reproduction also includes the "cultural forms and practices" that "maintain these differences and make them make sense" (Katz, 2017 p 1).

Such research makes visible the multitude of forms of gendered, raced, classed and even non-human labour, which produce value in, for, and against neoliberal capitalism (Bhattacharya 2017; Furgeson et al., 2016; Katz, 2017; McKeithen and Naslund, 2017). Under capitalism, spaces and times of bodily reproduction, like "eating, drinking and procreating," are only partially understood as "free" activities (Bhattacharya, 2017 p 11). Taking place outside of the formal wage economy, "absolute control over the time of reproduction" cannot be fully accounted for and exercised by an instituted capitalist system (Bhattacharya, 2017 p 11). We therefore concur with Bhattacharya (2017) that "much more theoretical attention needs to be paid to the relationship between the physical body in all its acts....and the social relationships of capital that such a body finds itself in" (p 11).
This is especially the case under conditions of neoliberal globalisation. If domestic labour was essential to the reproduction of a territorialised form of capital in the halcyon days of the nation state, then the transnationalization of social reproduction has been no less essential to "vagabond capitalism" in the 21st century (Katz, 2001). As V. Spike Peterson (2002) suggests, the global political economy can be understood as "three interacting, overlapping and co-existing economies-reproductive, productive, and virtual" ( $p$ 5). Within this triad, forms of reproductive labour-be they paid or unpaid, public or private, territorialised or not-constitute a key entry point to investigate myriad forms of economic and ideological asymmetries. These include gender ordering, racialization and exploitation, and ableism through processes that join the personal to the political and the local to the global through circuits of capitalist reproduction, consumption, and production. In this collection, we maintain that emotions and their relations to space and place help to understand how all those who produce and reproduce social worlds negotiate contradictory imperatives of compliance and resistance, oppression and enjoyment, valuation and devaluation that accompany such processes.

\section{Managing feelings as care work}

In 2003, Arlie Russell Hochschild's (1983) groundbreaking ethnography of US flight attendants was republished as a 20th anniversary edition. This signalled renewed interest in her novel concept of emotional labour, understood as the work of managing or performing specific, gendered, and context dependent feelings. For Hochschild, the work of performing compliance to certain "feeling rules" is an integral part of the successful execution of particular forms of paid labour. Attention to the production of expectations about the presentation of certain kinds of emotions in the course of performing gendered work "allows us to see how institutions-such as corporations-control us not simply through their surveillance of our behaviour, but through the surveillance of our feelings" (Hochschild, 1983 p 228). What matters here is not the "truth" of our feelings, per se, but our capacities or incapacities to produce embodied manifestations of the emotions deemed necessary to "get the job done". In this way, Hochschild emphasised emotions as both public and integral to the wage labour relation. Furthermore, the occupations for which this was true were also those that were on the rise in North America at the dawn of our neoliberal age, such as professional and technical workers, managers, service workers, domestic and sales workers, as well as those employed in clerical and kindred occupations (Hochschild, 1983 p 246).

More recently, Hochschild (2012 pp 11-21) examined how tasks relating to intimacy and care have become increasingly transnational and mediated by market-based actors, as exemplified by the explosion of technology-driven personal services. Analysing a range of intimate activities, including procuring care for a family member, planning a wedding, or entering into a commercial relationship with a surrogacy firm, she finds that consumers nevertheless make sense of these labours as ontologically distant and unrelated to processes of identity formation. The emotional labour that such consumers understand as central to their own production and reproduction as subjects remains the "naturalised" care of relationships not formally mediated by the market (Hochschild, 2012 p 224).

Hochschild's work has been broadly influential to studies of emotional and care labour that transcend conventional spatial containers such as the nation-state. This is the case for the field of care work, where "the extensive internationalisation of domestic services and its significance for the social relations of production 
and the division of labour" has been especially pronounced (Yeates, 2005 p 227). Nicola Yeates (2005) examines the inner workings of a "global domestic care regime" (p 229) in which the personal relationship of care is situated in a global business of care, and mediated through various gendered, racialized, economic hierarchies. In this collection, we similarly do not consider emotional and care labour as occurring in a vacuum. As with the global restructuring of care work, forms of emotional labour, too, are bound up with the particularities of place and economic sector, among other things. For instance, care and migration regimes are imbricated in any understanding of the global care business, as much as they are grounded in specific national contexts, themselves shaped by local cultural perceptions of care work, family expectations, and ideas about nationhood and responsibility thereto (Michel and Peng, 2012).

\section{Emotion and care work as spatial practices}

Feminist and cultural geographers have examined how emotions are spatial practices that are not merely individual, and are therefore enmeshed in power relations. Kay Anderson and Susan Smith (2001) observe "there are moments where lives are so explicitly lived through pain, bereavement, elation, anger, love and so on that the power of emotional relations cannot be ignored" (pp 7-8). However, far from existing in spatio-temporal isolation, the existence of "emotionally heightened spaces" underscores the broader truth that on some level, all social relations "are mediated by feelings and sensibility." In this view, emotions are intricate and active parts of social interactions. Following Sara Ahmed's (2004 pp 119-123) work, we maintain that emotions are transmitted, transformed, and circulated through affective economies, as a form of capital and a valued component of social interactions that help justify decisions, stances and takes on specific issues.

If emotions work in specific places and settings, this implies that attention cannot focus solely on the nature and essence of specific emotions. In emphasising the emotional dynamics of social interactions and power relations, Ben Anderson (2009) offers the concept of an "affective atmosphere" (pp 78). Affective atmosphere designates the ways in which emotions surface (or not) at specific moments because of a context in which specific affective relations take place. As bodies affect and are affected by each other, a look at emotions through their social dimensions grounds their meaning and significance in specific material and embodied realities that are both less-than-rational and morethan-rational (Anderson, 2006 pp 733-735). In this collection, we would therefore welcome social inquiries that focus on passions, gut-level decisions and so forth, in their relation to questions of rationality and decision-making.

This is especially important at this conjuncture, where the rise of far-right populism in Europe and North America is symptomatic of a widespread instrumentalization of negative feelings of middle and upper social classes to control the political discourse of public feelings (Anjaria, 2009; Greven, 2016; Kim, 2012). We reject any formulation or critique of populism that suggests the mere fact of emotion is the problem (i.e., Bardella, cited in Smith, 2018). Rather, we see the work of populism as one that often mobilises emotion in the service of nationalist, xenophobic, sexist, racist, ableist and heterosexualist reactions to neoliberal globalisation. Furthermore, such visceral reactions must be understood in the context of a dominant and relatively long standing neoliberal political rationality. This is a rationality that strives to render social interactions and power relations as strictly technical matters, stripped of public interest and ethical deliberation. In contrast to these public-and publically vilified-displays of collective emotional excess, the neoliberalization of emotional and care labour has generally meant a denial of the status of emotion and related areas of care and intimate life, as public concerns. As Aihwa Ong (2006) puts it these are: "non-political and nonideological problems that need technical solutions" (p 3).

The contributions gathered in this collection explore various facets of the "technicalization," "privatisation", and "individuation" of emotional and care labour as they unfold through specific spatial processes. As such they provide unique windows into the changing embodied realities and global political and economic experiences of our time.

\section{Article collection}

The initial papers published in this thematic collection ask how local and global processes create new challenges and opportunities for those who participate in, or are the object(s) of, forms of emotional and care labour. In so doing, they highlight emotions and affect as a key epistemological and methodological orientation for understanding under-explored linkages between local and intimate spatialities and broader political and economic processes. Contributors have brought a diverse range of disciplinary perspectives from Anthropology, Education, Labour Studies, Political Economy, and Sociology. They bring us into contact with different sites of enquiry, from urban informal settlements to transnationalized families and institutional and quasiinstitutional settings. The result is a rich and nuanced portrayal of what social reproduction and forms of emotional labour look like in our neoliberal present, across a range of geographic, political, social and economic circumstances.

Drawing on very different empirical case studies Wangui Kimari (2018) who writes about youth activism and care work in Kenya and Samantha Plummer (2018) who analyzes institutional restructuring in the US, both show us the different ways in which care work and affective relationships become sites through which forms of physical and structural violence are challenged and contested in neoliberal times. Kimari argues that the urban informal settlement of Mathare, Nairobi is normalised as a space of criminality, and therefore as a space not worthy of love or care. Youth activists engaged in providing essential services are therefore not simply providing "the reinstatement of basic rights". They are also, crucially, engaged in the work of reinserting "care and emotion in environments where a normalised (and militarised) precarity has denied the legitimacy of these sentiments."

Plummer's study looks at changing feeling rules for care workers in the wake of a corporate merger of Psychiatric Residential Treatment Facilities targeted towards "youth with emotional and behavioural issues" in the US. This merger brought increased neoliberal pressures for financial efficiency and accountability to bear on the work of the care providers concerned. However, in contrast to studies which find that these types of pressures produce emotional exhaustion and "burnout" Plummer's study yields the interesting insight that "in the face of value conflicts and increased coerciveness in the workplace relationships with service recipients can become more apparently pleasurable and serve as sites of compensatory solace."

Foregrounding parenting as both socially valuable and emotionally fulfilling work, Tobin LeBlanc Haley (2017) shows how the constellation of law, governance, and space works to constrain the intimate lives of Mad women living in supported housing in Ontario, Canada. In this case we see how certain forms of emotional and care labour are effectively prohibited by a political, economic, and spatial relation that simultaneously withholds legal rights and the possibility of certain emotional relationships from some women. As with Kimari and Plummer, LeBlanc Haley shows how neoliberal techniques of management and surveillance erode and undermine the intrinsic value of care and emotional 
connections. However, as all three papers underscore, making these forms of labour and their embodied value visible and legible is an essential part of the political project of thinking and acting towards a different future.

Beginning from an understanding of migration as a "livelihood strategy," Oksana Schmulyar Gréen and Charlotte Melander (2018) examine how Polish and Romanian migrant workers in Sweden negotiate family obligations since the accession of their countries to the European Union. In an empirically rich article, they show how migrant mothers frame the experience of separation from their children as more of a negative emotional experience than do migrant fathers. Thus, within these transnationally "split households" the division of caring responsibilities for parents remains central to the reproduction of traditional gender roles. However, such roles are not as important as, and are rooted in a broader ideas surrounding "good parenthood", understood as a product of individual familial self-sufficiency. "Good parenthood", Gréen and Melander argue, allows parents to justify and situate decision making about the care of children within the transnationalized household through a complex configuration of factors. These include the nature of the family structure, the age and needs of children, as well as the reasons for migration in the first place.

O'Keeffe's (2018) contribution looks at the experiences of men who teach young children in the Irish education system. For O'Keeffe, these men's experiences of gendered care work offer a unique entry point into the social and spatial economies of emotion. Drawing on interviews with male caregivers, she shows how these men interpret themselves and their work in view of broader social understandings of "men who perform emotional labour”. Drawing on Sarah Ahmed's work, O'Keeffe underscores emotions as socially bifurcated between "signs of cultivation" and "signs of weakness". Emotions therefore create "a social presence rather than a self-presence" and it is "through emotions, or how we respond to objects and others, that boundaries are made." The example of men who care for young children therefore underscores the extent to which different forms of work come not only with certain "feeling rules" à la Hochschild but also with complex and shifting assumptions about which kinds of bodies are appropriate to the emotional economies in question.

Received: 12 March 2018 Accepted: 20 March 2018

Published online: 17 April 2018

\section{Notes}

1 Parish and Montsion (eds) Geographies of emotional and care labour. Palgrave Communicatons. https://www.nature.com/collections/fxpksyttls/

\section{References}

Ahmed S (2004) Affective economies. Social Text 22(2):117-139

Anderson B (2006) Becoming and being hopeful: towards a theory of affect. Environ Plan D 24:733-752

Anderson B (2009) Affective atmospheres. Emot Space Soc 2:77-81

Anderson K, Smith S (2001) Emotional geographies. Trans Inst Br Geogr 26 (1):7-10

Andrucki M Henry C, McKeithen W, Stinard-Keil SA (2017) Intro: beyond binaries and boundaries in 'social reproduction'. Society and Space. http:// societyandspace.org/2017/10/31/intro-beyond-binaries-and-boundaries-insocial-reproduction/. Accessed 30 Jan 2018

Anjaria J (2009) Guardians of the Bourgeois City: Citizenship, Public Space, and Middle-Class Activism in Mumbai. City Community 8(4):391-406

Bhattacharya T (2017) Introduction: mapping social reproduction theory. In: Bhattacharya $\mathrm{T}(\mathrm{ed})$ Social reproduction theory: remapping class, recentering oppression. Pluto Press, London

Furgeson S, LeBaron G, Dimitrakaki A, Farris SR (2016) Special issue on social reproduction. Hist Mater 24(2):25-37

Green OS, Melander C (2018) Family obligations across European borders: negotiating migration decisions with the families of post-accession migrants in Sweden. Palgrave Commun 4:28. https://doi.org/10.1057/s41599-0180084-x

Greven T (2016) The rise of right-wing populism in Europe and the United States. Perspective, Friedrich Ebert Stiftung, Washington. http://www.fesdc.org/ fileadmin/user_upload/publications/RightwingPopulism.pdf. Accessed 10 Mar 2018

Hochschild A (1983) The managed heart: commercialization of human feeling. University of California Press, Oakland

Hochschild A (2012) The outsourced self: intimate life in market times. Metropolitan Books, New York

Irigaray L (1985) Speculum of the other woman. Cornell University Press, Ithaca

Katz C (2001) Vagabond capitalism and the necessity of social reproduction. Antipode 33(4):709-728

Katz C (2017) Social reproduction. In: Richardson D et al. (eds) The international encyclopedia of geography: people, the earth, environment and technology. Wiley \& Sons Ltd, Oxford

Kim NHJ (2012) Multiculturalism and the politics of belonging: the puzzle of multiculturalism in South Korea. Citizsh Stud 16(1):103-117

Kimari W (2018) Activists, care work, and the 'Cry of the Ghetto' in Nairobi, Kenya. Pal Commun 4(23) https://doi.org/10.1057/s41599-018-0078-8

Laporte D (2002) History of shit. MIT Press, Cambridge

LeBlanc Haley T (2017) Intimate constraints: a feminist political economy analysis of biological reproduction and parenting in high-support housing in Ontario. Pal Commun 3(50). https://doi.org/10.1057/s41599-017-0053-9

McKeithen W, Naslund S (2017) Worms and workers: placing the more-thanhuman and the biological in social reproduction. Society and Space. http:// societyandspace.org/2017/11/14/worms-and-workers-placing-the-morethan-human-and-the-biological-in-social-reproduction/. Accessed 30 Jan 2018

Michel S, Peng I (2012) All in the Family? Migrants, Nationhood, and Care Regimes in Asia and North America. J Eur Social Policy 22(4):406-418

O'Keeffe S (2018) Experiences of care labour, gender and work for men who teach young children. Pal Commun

Ong A (2006) Neoliberalism as exception: mutations in citizenship and sovereignty. Duke University Press, Durham

Peterson VS (2002) Rewriting (Global) political economy as reproductive, productive, and virtual (Foucauldian) economies. Int Fem J Polit 4(1):1-30

Plummer S (2018) Emotion management, institutional change, and the spatial arrangement of care at a psychiatric residential treatment facility. Pal Commun 4(6) https://doi.org/10.1057/s41599-017-0058-4

Sartre JP (1960) Esquisse d'une théorie des émotions. Hermann, Paris

Sears A (2016) Situating sexuality in social reproduction. Hist Mater 24(2):138-163

Smith D (2018) Hollowed out' White House: Trump is on a dangerous path toward no advisers. The Guardian. Saturday https://www.theguardian.com/us-news/ 2018/mar/10/hollowed-out-white-house-trump-is-on-a-dangerous-pathtoward-no-advisers. Accessed 10 Mar 2018

Yeates N (2005) A global political economy of care. Social Policy Soc 4(2):227-234

\section{Additional information}

Competing interests: The authors declare no competing interests.

Reprints and permission information is available online at http://www.nature.com/ reprints

Publisher's note: Springer Nature remains neutral with regard to jurisdictional claims in published maps and institutional affiliations.

\section{(i)}

daptation, distribu And reproduction in any medium or format, as long as you give appropriate credit to the original author(s) and the source, provide a link to the Creative Commons license, and indicate if changes were made. The images or other third party material in this article are included in the article's Creative Commons license, unless indicated otherwise in a credit line to the material. If material is not included in the article's Creative Commons license and your intended use is not permitted by statutory regulation or exceeds the permitted use, you will need to obtain permission directly from the copyright holder. To view a copy of this license, visit http://creativecommons.org/ licenses/by/4.0/

(C) The Author(s) 2018 